\title{
Plinian pumice fall deposit of the Campanian Ignimbrite eruption (Phlegraean Fields, Italy)
}

\author{
M. Rosi ${ }^{\mathrm{a}, *}$, L. Vezzoli ${ }^{\mathrm{b}}$, A. Castelmenzano ${ }^{\mathrm{b}}, \mathrm{G}$. Grieco ${ }^{\mathrm{b}}$ \\ ${ }^{a}$ Università degli Studi di Pisa, Dipartimento di Scienze della Terra, via S. Maria 53, 56126 Pisa, Italy \\ ${ }^{\mathrm{b}}$ Università degli Studi di Milano, Dipartimento di Scienze della Terra, via Mangiagalli 34, 20133 Milan, Italy
}

\begin{abstract}
A plinian pumice fall deposit associated with the Campanian Ignimbrite eruption (36 ka, Phlegraean Fields caldera, Italy) occurs at the base of the distal grey ignimbrite in 15 localities spread over an area exceeding $1500 \mathrm{~km}^{2}$ between Benevento and the Sorrentina peninsula. In the thickest stratigraphic section at Voscone $(130 \mathrm{~cm}), 45 \mathrm{~km}$ east of the Phlegraean caldera centre (Pozzuoli), the deposit consists of two units: the lower fall unit (LFU) is well sorted, exhibits reverse size grading and is composed of equidimensional light-grey pumice clasts with very subordinate accidental lithics; the upper fall unit (UFU) is from well to poorly sorted, crudely stratified, richer in lithics and composed of both equidimensional and prolate pumice clasts. The two fall units show slightly different dispersal axis: N90 for the LFU and $\mathrm{N} 95^{\circ}$ for the UFU. Volumes calculated with the method of Pyle (1989) are about $8 \mathrm{~km}^{3}$ for the LFU and $7 \mathrm{~km}^{3}$ for the UFU. The maximum height of the eruptive columns are estimated, using the model of the maximum lithic clasts dispersal, at $44 \mathrm{~km}$ for the LFU and $40 \mathrm{~km}$ for the UFU, classifying both fall units as ultraplinian in character. Reverse size grading within the LFU suggests an increase of the height of the column and magma discharge rate with time. Moderate sorting and crude stratification of the UFU are consistent with short-period oscillation of the column, possibly associated with repeated partial column collapses. Sharp increases in lithic content at the transition to UFU and within the UFU suggest that changes in the eruptive behaviour was produced by a dramatic increase in conduit/vent erosion. The phase of column instability preceded the emplacement of widely dispersed pyroclastic flow. The ultraplinian nature of the fall fits well with the wide dispersal of the Campanian Ignimbrite with an estimated aspect ratio of $3-4 \times 10^{-4}$ (LARI). (C) 1999 Elsevier Science B.V. All rights reserved.
\end{abstract}

Keywords: Campanian Ignimbrite; Phlegraean Fields caldera; plinian eruption; plinian fall deposit; tephrostratigraphy; eruptive dynamics

\section{Introduction}

The Campanian Ignimbrite (CI) eruption is the major explosive event in the Late Quaternary of the Mediterranean region (Barberi et al., 1978). It erupted at least $80 \mathrm{~km}^{3}$ DRE of trachytic magma (Thunell et al., 1979) and deposited about $500 \mathrm{~km}^{3}$ in bulk

\footnotetext{
* Corresponding author
}

volume of tuff (Fisher et al., 1993) 36,000 years ago (Deino et al., 1992) from the Phlegraean Fields caldera (Rosi and Sbrana, 1987). Fisher et al. (1993) have confirmed the source of the CI eruption as within the Phlegraean Fields caldera and the occurrence of a co-genetic plinian pumice fallout in the distal eastern and southeastern CI sequence. By studying the proximal CI lag-deposits Rosi et al. (1996) have reconstructed a sequence of ignimbrites 


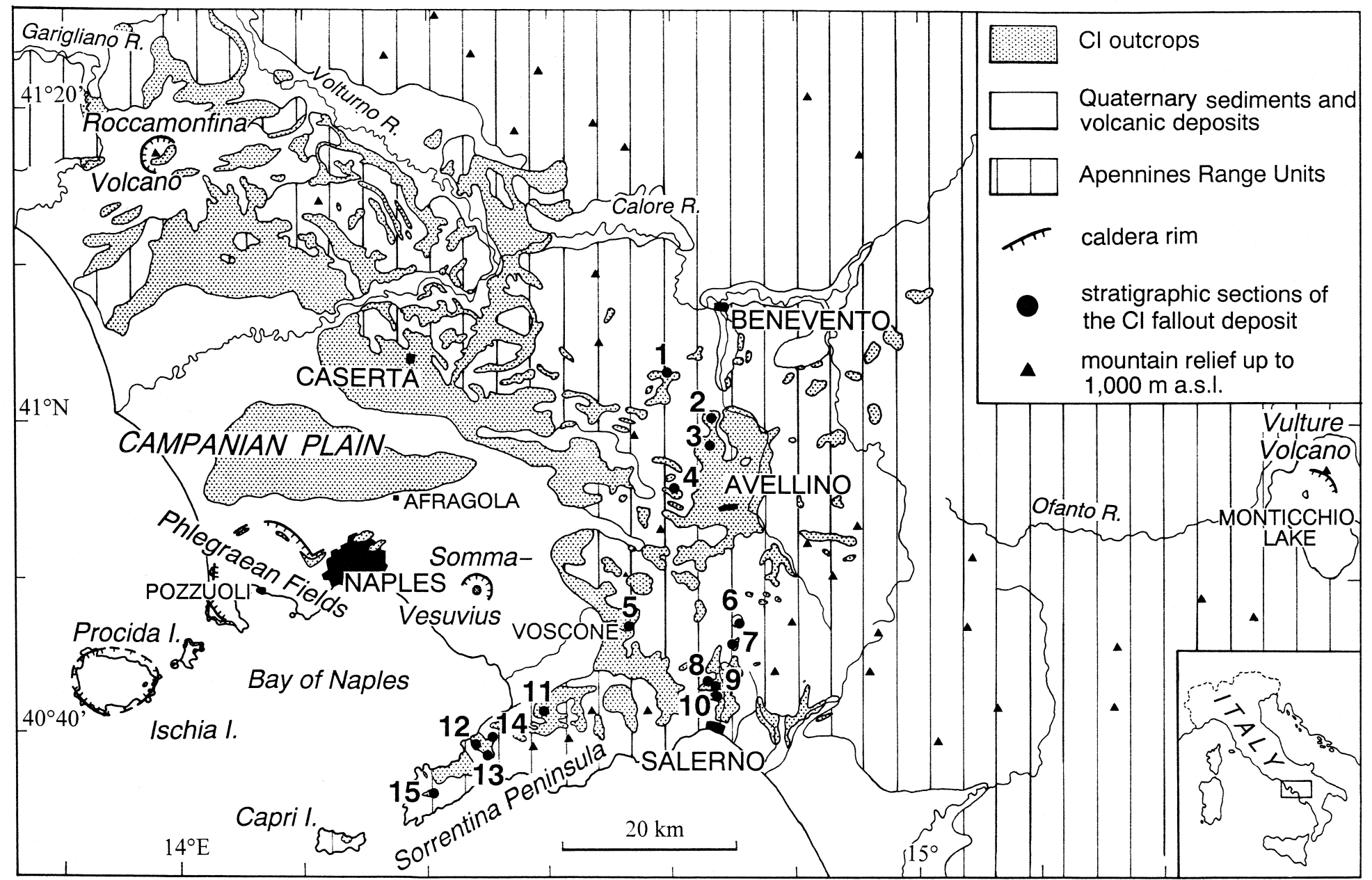

Fig. 1. Areal distribution of the Campanian Ignimbrite and location of the stratigraphic sections of the plinian fall deposit related to the Campanian Ignimbrite eruption. (1) Tufara, (2) Starza, (3) Sant'Angelo a Scala, (4) Acqua Fidia, (5) Voscone, (6) Tufarella, (7) Penta, (8) Copecchia, (9) Pellezzano, (10) Capezzano, (11) Casola, (12) Vico Equense, (13) Pacognano, (14) Massaquano, (15) Monticchio. 
and lithic-rich breccias, which probably record the interaction between eruptive activity and caldera collapse episode(s). The CI plinian fall has not been identified near the caldera.

This work presents new lithostratigraphic, grainsize, component and compositional data on the plinian pumice fall deposit related to the CI eruption.

The CI plinian pumice fall deposit was recognized over an area exceeding $1500 \mathrm{~km}^{2}$ east of Phlegraean Fields and Somma-Vesuvius, between Benevento and Salerno, and on the Sorrentina peninsula (Fig. 1).

The fall deposit was also recovered in a core drilled in the sediments of the Monticchio Lake at Monte Vulture volcano, $120 \mathrm{~km}$ east of the Phlegraean Fields caldera (Narcisi, 1996). Here the CI pumice fall bed is $15 \mathrm{~cm}$ thick and is overlain by a 3-cm-thick vitric ash. ${ }^{40} \mathrm{Ar} /{ }^{39} \mathrm{Ar}$ single-crystal dates from feldspars $(n=8)$ of the CI pumice in the Monticchio core have yielded an age of $37 \pm 0.3 \mathrm{ka}$ (B. Narcisi, pers. commun.) in good agreement with the age of the CI.

\section{Stratigraphy}

The first descriptions of the pumice fall deposit underlying the CI grey ash-flow tuff are of Scacchi (1888) and Galdieri and Paolini (1914). Di Girolamo et al. (1973) considered this pumice layer as the product of a separate older eruption. In the Apennines Range surrounding the Campanian Plain, field and compositional data indicate the existence of two groups of pumice outcrops related to two different eruptions. The northern (near Caserta) pumice fall is trachy-phonolitic in composition, separated by a paleosol from the CI grey ash-flow tuff and represents the deposit of an older eruption, likely derived from the Phlegraean Fields. The eastern pumice fall directly underlies the CI grey ash-flow tuff and is trachytic in composition. We consider it to be related in time to the CI eruption because: (a) there is no paleosol or weathering at the contact; (b) grey ashflow tuff overlies the fall deposit in all localities; (c) the only erosion present is that caused by the pyroclastic flow.

We have identified and measured 15 stratigraphic sections at distances between 32 and $61 \mathrm{~km}$ from the Phlegraean caldera centre (Pozzuoli) (Fig. 1). The CI fall is not exposed in the Campanian Plain because of its burial under younger volcanic and sedimentary deposits and the lack of deep erosion.

All measured outcrops reported in Fig. 1 are flat lying and lack erosion by the overlying ignimbrite. Clear evidence of erosion from CI pyroclastic flow has been observed in several outcrops in the investigated area. In the most extreme cases, the fall has been completely removed whereas in other cases traces of its deposition are represented by relict pumices and lithics at the base of the scouring CI pyroclastic flow.

The CI plinian fall deposit is composed essentially of pumice, with minor quantities of accidental lithic fragments and free crystals, and it is always underlain by a brown (10YR3/2 Munsell Chart) paleosol and underlies the main ignimbrite (Fig. 2). A low-grade, ash-rich ignimbrite with a maximum thickness of $2 \mathrm{~m}$ locally is interposed at the contact between the CI welded facies and the fall deposit (Fig. 3).

The Voscone stratigraphic section (Fig. 4), located $45 \mathrm{~km}$ east of the Phlegraean Fields caldera centre (Pozzuoli) in an inactive tuff quarry, was chosen as type-section. Here the deposit shows: (a) no evidence of erosion or reworking; (b) the maximum observed thickness $(130 \mathrm{~cm})$; (c) proximity to the overall dispersal axis.

The fall deposit can be divided in two units on the basis of an abrupt change in colour, abundance of lithic clasts, type of pumice clasts and grain-size at approximately mid-level. The lower fall unit (LFU) consists of a light-grey, reverse graded pumice deposit; the upper fall unit (UFU) is rose-brown in colour, richer in ash and lithics. No evidence of temporal breaks occur between these two units.

Stratigraphic correlations between 12 of the more significant sections are presented in Fig. 5. The thickness ratio of UFU to LFU increases from $\mathrm{N}$ to S. UFU and LFU are absent respectively in the northernmost and southernmost outcrops.

The LFU is a coarse-grained, from very well to well sorted pumice deposit with subordinated accidental lithics, crystals and rare obsidian clasts. Pumice clasts are light-grey to whitish in colour, equidimensional, angular, and from highly to extremely vesicular (Houghton and Wilson, 1989) with spherical vesicles. Lithics are angular and consist 

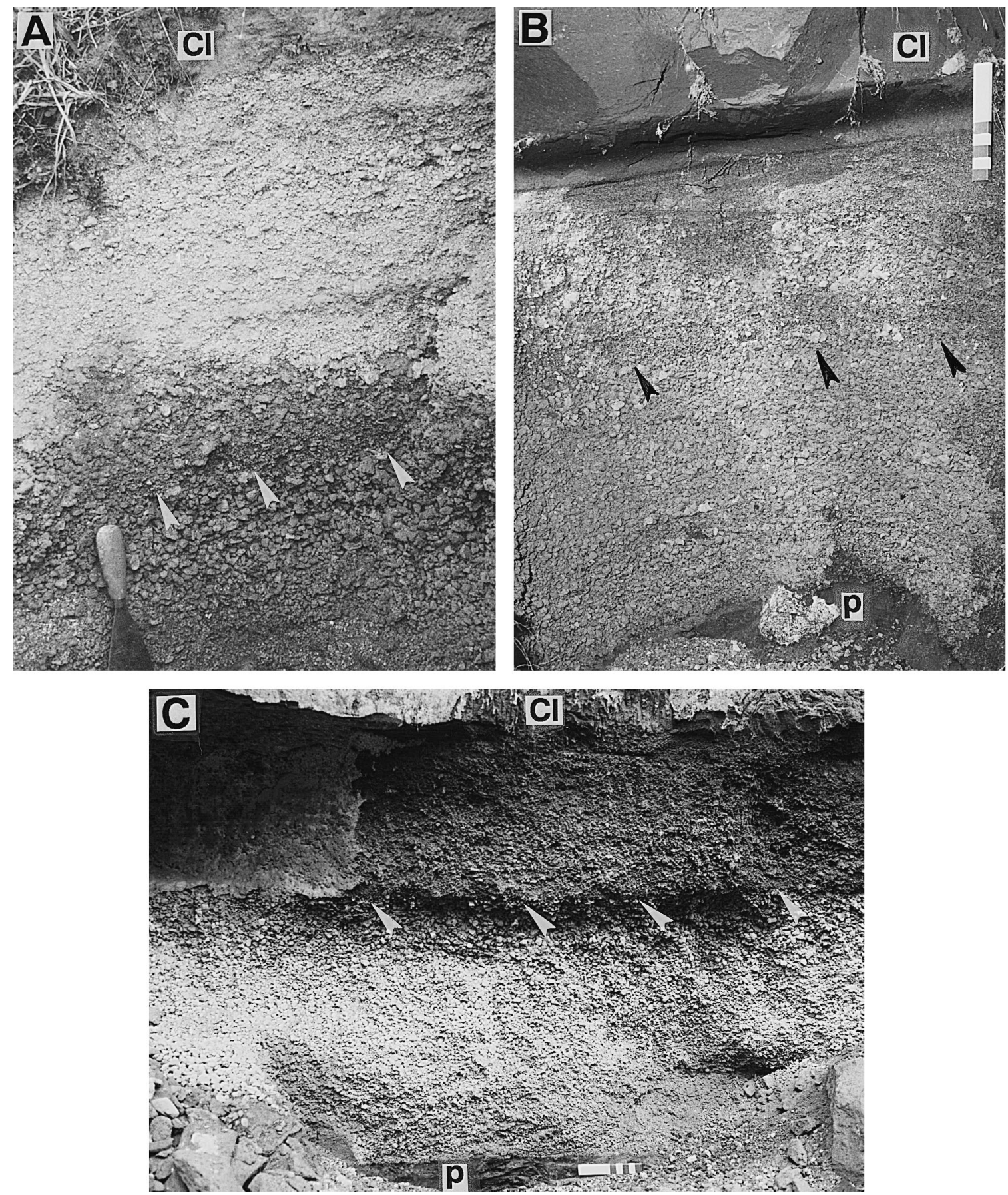

Fig. 2. The Campanian Ignimbrite pumice fall deposit at (A) Pellezzano (sec. 9), (B) Acqua Fidia (sec. 4) and (C) Voscone (sec. 5). p: paleosol; CI: sintered facies of Campanian Ignimbrite; arrows point to the LFU and UFU contact. See Fig. 1 for location.

mainly of trachytic fresh lavas ( $>75$ number \%), subordinate more basic lavas (latites, trachybasalts and tephrites) and rare pyroclastic rocks and rocks of deep origin (subvolcanic syenites and sedimentary 


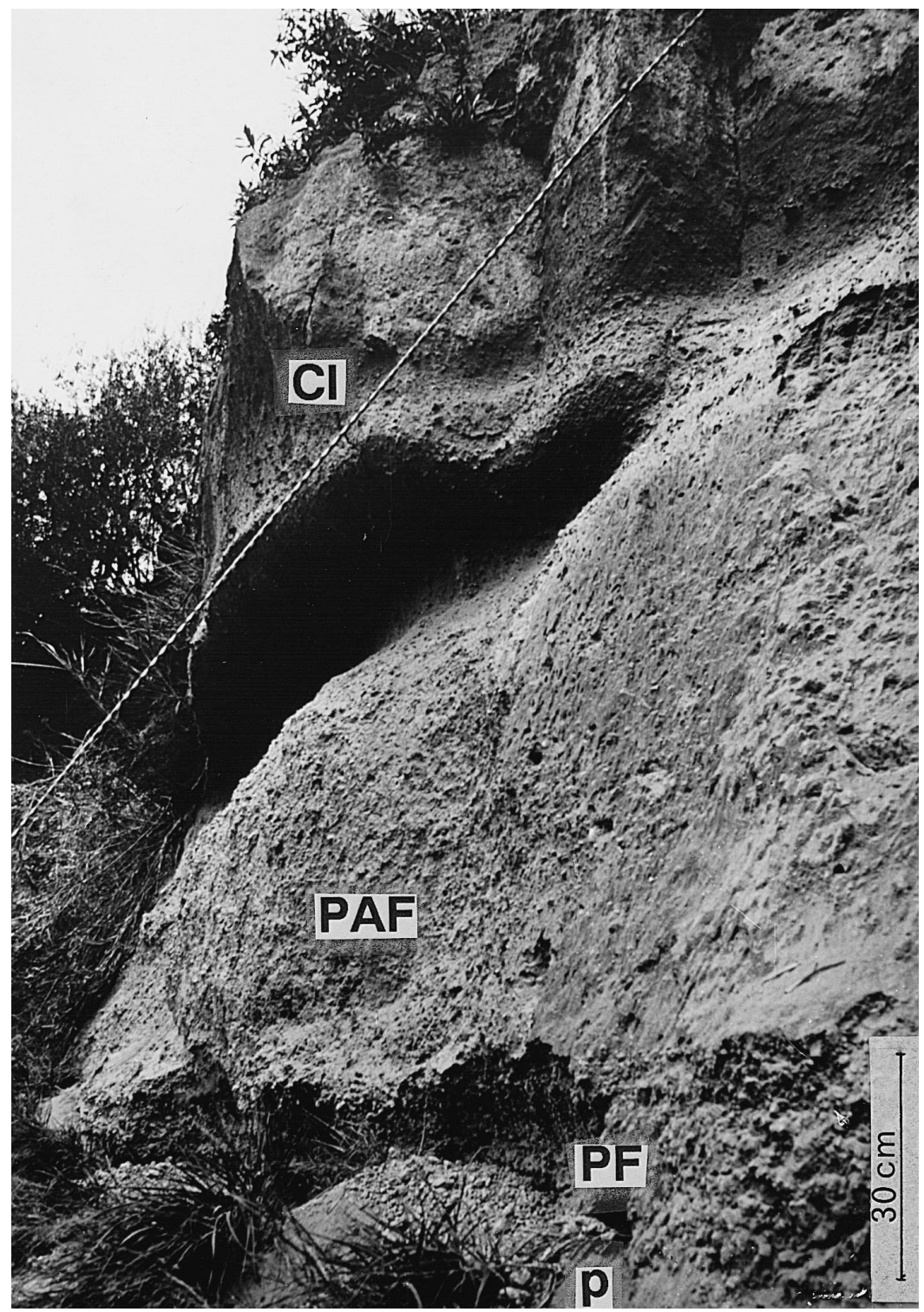

Fig. 3. The products of the Campanian Ignimbrite eruption at Vico Equense (sec. 12, Fig. 1). In foreground the plinian pumice fall deposit $(\mathrm{PF})$ is $30 \mathrm{~cm}$ thick and overlies a paleosol (p). Note the occurrence of an unwelded pumice and ash flow deposit (PAF), $2 \mathrm{~m}$ thick, between the fallout and the sintered facies of Campanian Ignimbrite (CI).

rocks). Crystals are dominantly fragments of sanidine of grain size to $4-5 \mathrm{~mm}$; pyroxene and biotite have grain size smaller than $2 \mathrm{~mm}$ and are rare. Both pumices and lithics exhibit reverse size grading, more evident towards the base. Thickness varies from $4 \mathrm{~cm}$ at Massaquano (sec. 14) to $84 \mathrm{~cm}$ at Voscone (sec. 5) (Fig. 5). On the basis of grain-size characteristics, the LFU of Voscone type-section have been conveniently subdivided into three sub-units with gradational boundaries, named from bottom to top: V1, V2 and V3 (Fig. 4). V1 is $30 \mathrm{~cm}$ thick and shows evident reverse size grading and very scattered lithic clasts; V2 is $33 \mathrm{~cm}$ thick and moderately reversely graded; V3 is $21 \mathrm{~cm}$ thick and coarser, not 


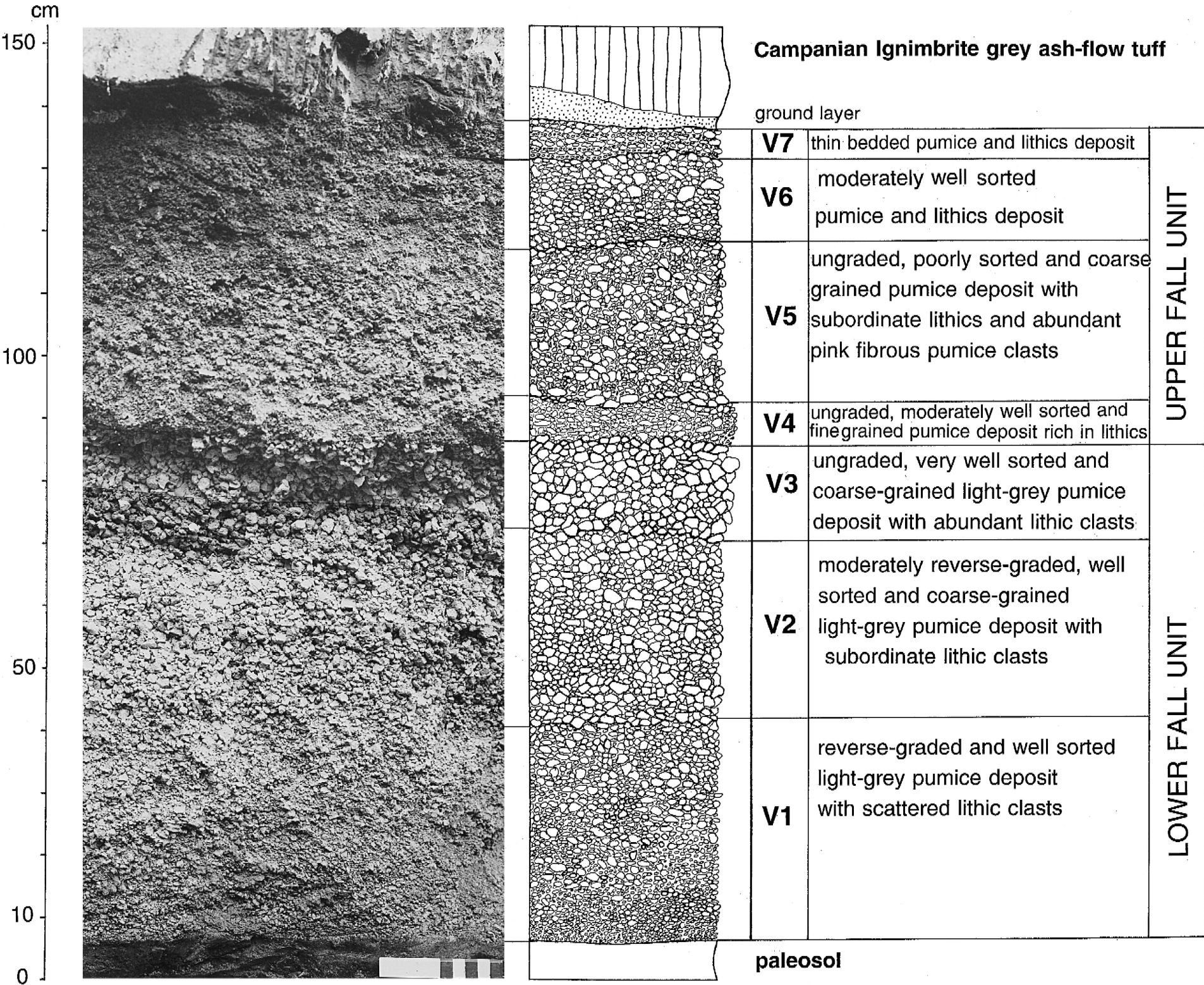

Fig. 4. Lithology, nomenclature and eruptive sequence of the Campanian Ignimbrite plinian fall deposit in the stratigraphic type-section of Voscone (sec. 5, Fig. 1). 


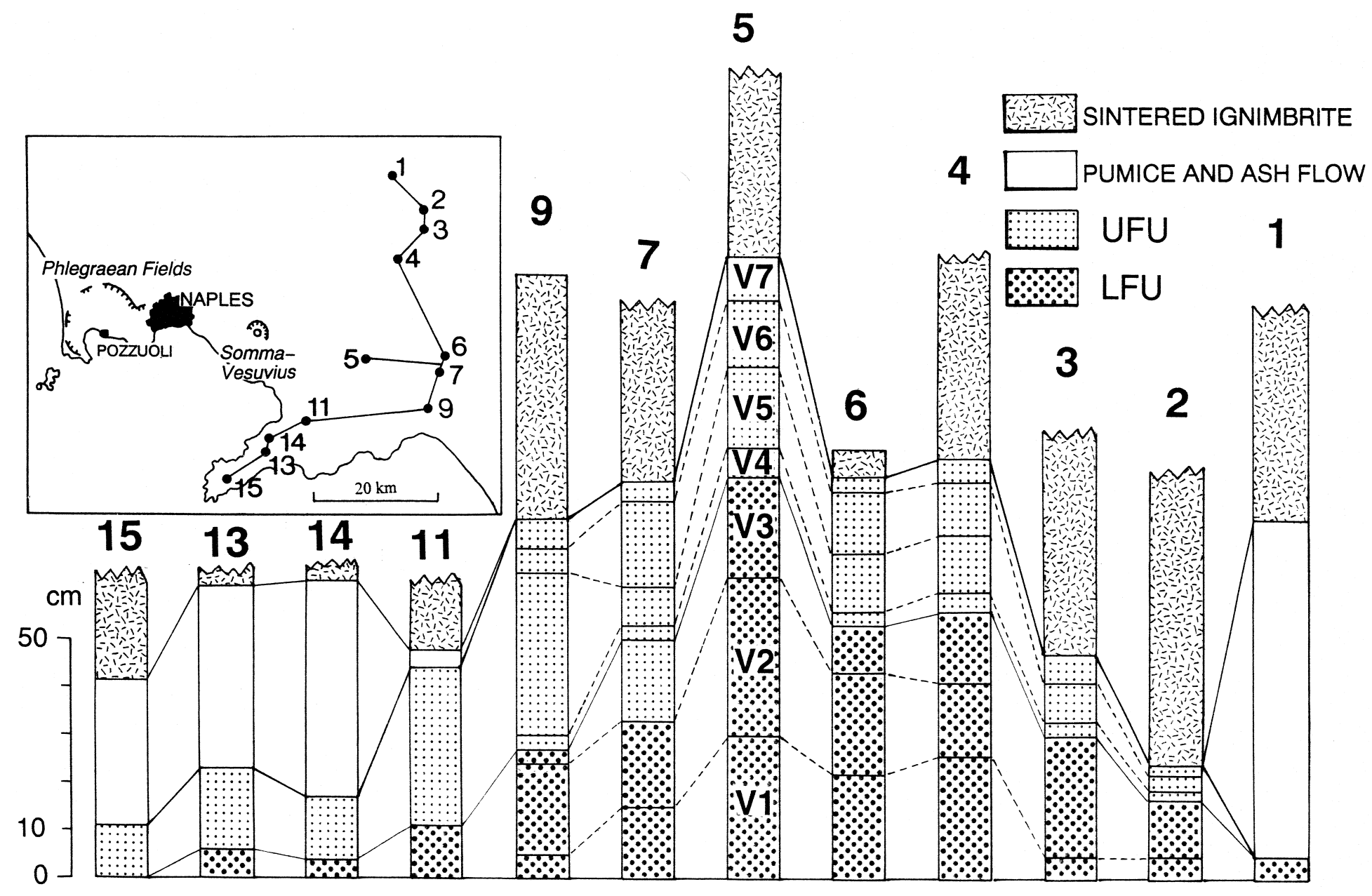

Fig. 5. Stratigraphic correlations of Campanian Ignimbrite plinian fall deposit. Location of the stratigraphic sections shown in Fig. 1. 
graded and very well sorted. Extremely vesicular, low-density and very friable pumice bombs are also present. The LFU internal subdivision proposed for the Voscone type-section is recognizable also in other stratigraphic sections located near the dispersal axis (sec. 4 Acqua Fidia, sec. 6 Tufarella, sec. 7 Penta, sec. 9 Pellezzano; Fig. 5). In the other studied stratigraphic sections, the reverse size grading of the LFU is unclear and the sub-units V1, V2 and V3 are not identifiable. The boundary between LFU and UFU is abrupt and sharp.

The UFU is pink-brownish, crudely stratified, from well to poorly sorted pumice deposit, with relatively abundant accidental lithics and subordinate crystals and obsidian clasts. Three types of pumice clasts are present: (a) equidimensional with spherical vesicles; (b) elongate stick-shaped with tubular vesicles; (c) extremely vesicular and very friable. Lithics are angular to subangular and composed of trachytic lavas (74 number \%) and subordinate pyroclastic rocks and subvolcanic syenites. Free crystals consist almost entirely of both fragmented and idiomorphic sanidine with grain size to $4-5 \mathrm{~mm}$; pyroxene and biotite are smaller than $2 \mathrm{~mm}$ and are rare. Both pumices and lithics show overall normal grading from bottom to top. Thickness varies from $7 \mathrm{~cm}$ ( $\mathrm{sec}$. 2 Starza) to $48 \mathrm{~cm}$ (sec. 9 Pellezzano) (Fig. 5). In the Voscone type-section four sub-units with gradational boundaries have been distinguished, from the bottom to the top: V4, V5, V6 and V7 (Fig. 4). V4 is $6 \mathrm{~cm}$ thick, fine-grained, not graded and moderately well sorted, with an abundant coarse ash fraction and high lithic and obsidian content. In V4, the first appearance of stick-shaped fibrous pumice occurs. These clasts are more abundant in the $<2 \mathrm{~mm}$ grain size class. V5 is $17 \mathrm{~cm}$ thick, light brown in colour, coarse grained, ungraded and the worst sorted of the UFU beds. The stick-shaped pumices are prevalent in the grain size class to $4 \mathrm{~mm}$. Low-density and extremely vesiculated pumice bombs are present. Lithics are subordinate and obsidian clasts are rare. V6 is $14 \mathrm{~cm}$ thick, crudely normally graded, with a higher obsidian content. V7 is $9 \mathrm{~cm}$ thick, the finest UFU bed, and moderately well sorted. A very thin layering is defined by changes in grain-size and colour, that can vary from brown to grey and pink. Clasts are coated with ash and accretionary lapilli sporadically occur at the top of this bed. The V4 and
V7 beds are easily recognized in the entire dispersal area except in the Sorrentina peninsula. The subdivision between V5 and V6 is visible only in the stratigraphic sections near the dispersal axis (sec. 4 Acqua Fidia, sec. 6 Tufarella, sec. 7 Penta, sec. 9 Pellezzano; Fig. 5).

\section{Grain-size characteristics}

Dry sieve analyses at $1 \Phi$ interval between $-4 \Phi$ and $+4 \Phi$ were carried out on 23 samples collected from Voscone (7), Acqua Fidia (8) and Pellezzano (8) sections.

In $\operatorname{Md} \Phi / \sigma \Phi$ and $\mathrm{F} 1 / \mathrm{F} 2$ diagrams (Fig. 6) all CI fall samples plot in the field of fall deposits of Walker (1983). However, UFU and LFU samples form distinct fields. LFU data form narrow fields $(\mathrm{Md} \Phi=-3.32$ to $-1.77, \sigma \Phi=0.85$ to $1.25 ; \mathrm{F} 1=$ 10.74 to $2.33, \mathrm{~F} 2=2.97$ to 0.77 ), while UFU values are more scattered $(\mathrm{Md} \Phi=-2.14$ to $0.07, \sigma \Phi=1.12$ to $1.92 ; \mathrm{F} 1=47.14$ to $8.89, \mathrm{~F} 2=11.56$ to 0.96$)$ and plot closer to the field of pyroclastic flows.

Variation of grain-size parameters as a function of stratigraphic height in the Voscone type-section is shown in Fig. 7.

LFU is coarser grained and better sorted, with $\operatorname{Md} \Phi$ values ranging from -3.32 to -2.24 , while $\sigma \Phi$ values range from 1.01 to 1.25 . Both $\operatorname{Md} \Phi$ and $\sigma \Phi$ show a well defined negative trend with stratigraphic height from bottom to top of LFU. The reverse size-grading is found in both pumice and lithic clasts: from bottom to top pumice $\operatorname{Md} \Phi=$ -2.09 to -3.49 and lithics $\operatorname{Md} \Phi=-1.00$ to -2.11 . The fraction coarser than $4 \mathrm{~mm}$ increases in abundance towards the top, reaching maximum values of more than $80 \mathrm{wt} . \%$; the fraction finer than $1 / 4 \mathrm{~mm}$ never exceeds $5 \mathrm{wt} \%$ and decreases upwards. MP and ML values match the granulometric analyses showing trends that strictly follow that of $\mathrm{Md} \Phi$. Both reach maximum values in $\mathrm{V} 3(\mathrm{ML}=2.5$; $\mathrm{MP}=5.5)$ and the size of maximum lithic clasts thus almost doubled during the eruption of the LFU.

UFU is finer-grained and more poorly sorted than LFU. At the V4 layer a drastic variation in grain size parameters happens. $\operatorname{Md} \Phi$ and $\sigma \Phi$ are -0.72 and 1.46 , respectively. In the overlying layers V5, V6 

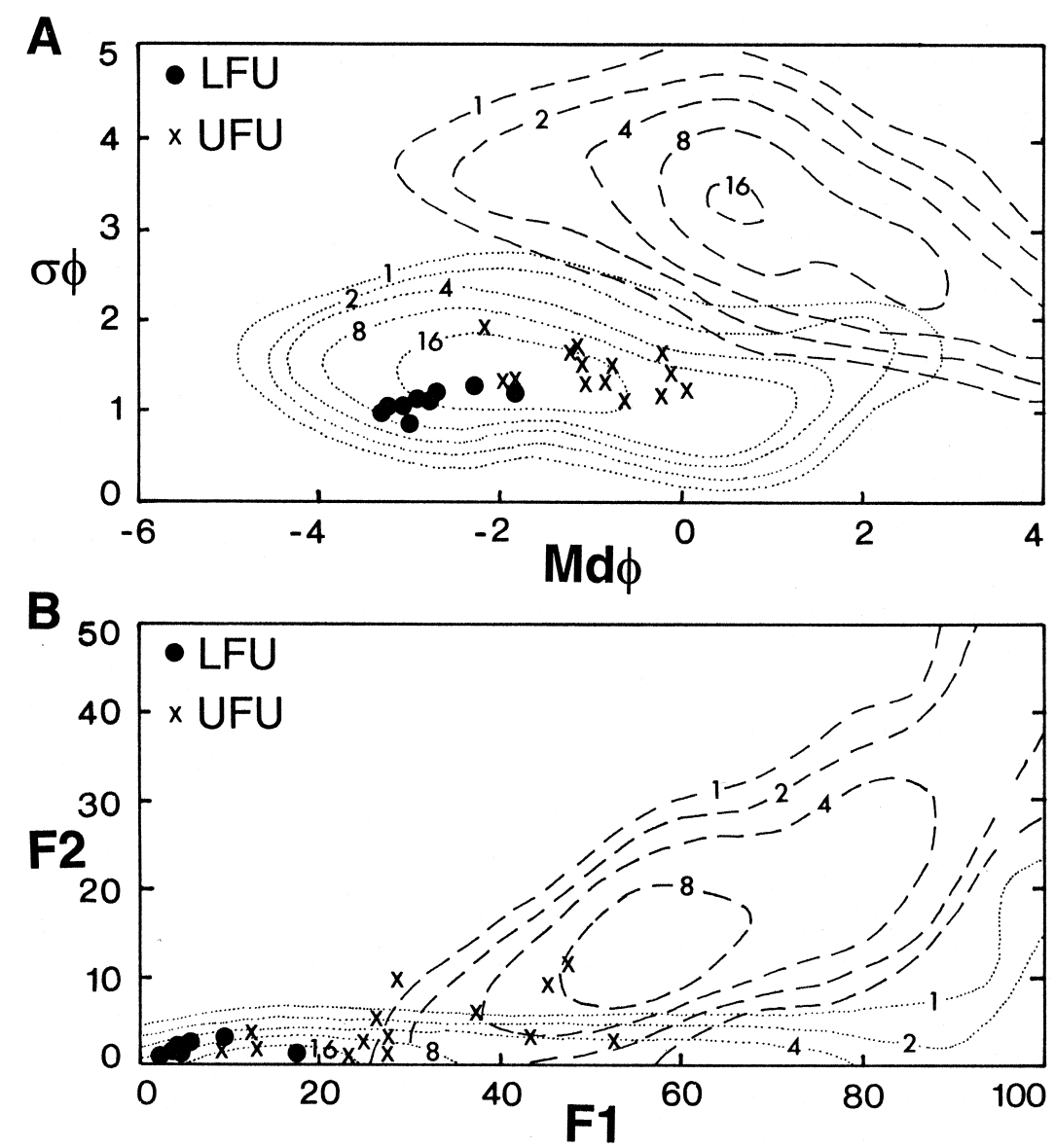

Fig. 6. Grain size characteristics of the plinian fall deposit of the Campanian Ignimbrite eruption in the Voscone (sec. 5), Acqua Fidia (sec. 4) and Pellezzano (sec. 9) stratigraphic sections: (A) median diameter (Md $\Phi)$ vs. sorting $(\sigma \Phi)$; (B) wt. $\%<1 \mathrm{~mm}(\mathrm{~F} 1)$ vs. wt.\% $<63 \mu \mathrm{m}$ (F2). Fields for fines-rich ignimbrites (dashed lines) and fall deposits (dotted lines) from Walker (1983). Weight of samples ranged from 0.9 to $1.5 \mathrm{~kg}$. Sieving were performed from $-4 \Phi$ to $4 \Phi$, of $1 \Phi$ interval.

and V7 $\operatorname{Md} \Phi$ decreases regularly from -2.14 to -0.10 and $\sigma \Phi$ increase from 1.94 to 1.64 . Normal size grading is shown by both pumice and lithic clasts: from bottom to top pumice $\operatorname{Md} \Phi=-1.52$ to -0.89 and lithics $\operatorname{Md} \Phi=-0.26$ to 0.17 . The coarse fraction $(>4 \mathrm{~mm}$ ) strongly decreases upwards, with values from about 50 to $7 \mathrm{wt} . \%$; conversely the fine fraction $(<1 / 4 \mathrm{~mm})$ increases from about $5 \mathrm{wt} . \%$ to more than $15 \mathrm{wt} . \%$. MP and ML show maximum values in V5 $(\mathrm{ML}=2.3 ; \mathrm{MP}=5.9)$. These values are like those of the V3 (LFU). Layer V5 as well as the rest of UFU also contain a significant amount of fine material, a fact which result in a appreciable increase of $\sigma \Phi$ values (1.94). Because the fall is faintly stratified throughout and maximum lithic and pumice clasts are scattered, we suggest that the whole UFU resulted from the successive showers of coarse and fine pyroclasts and that only occasionally the column reached heights comparable to that of V3.

\section{Density and composition of pumice clasts}

Determination of clast density in Voscone typesection was carried out on 70 samples in the size fraction $-4 /-5 \Phi$ (10 from each of the seven 

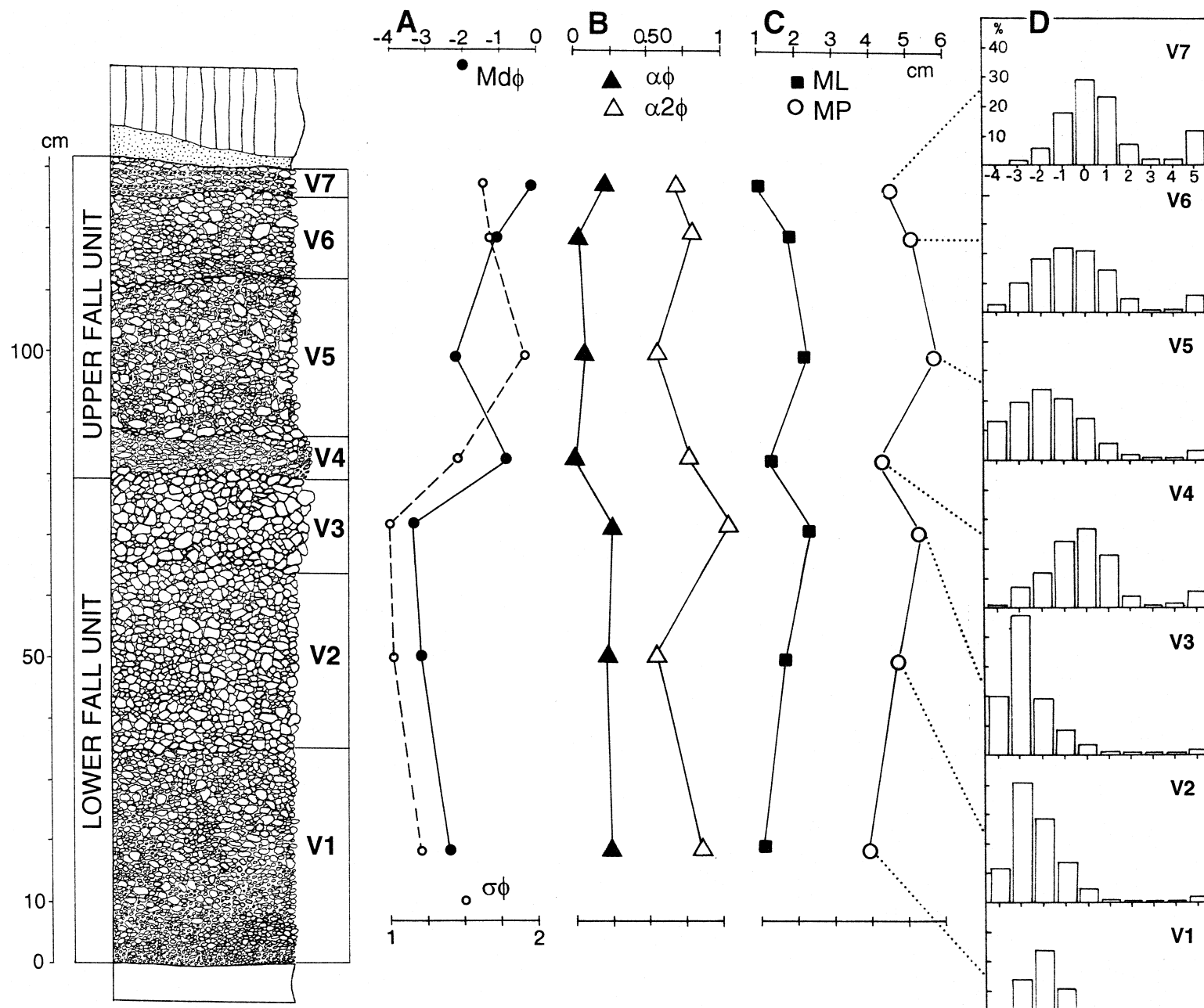

V7

$-20$

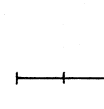

1

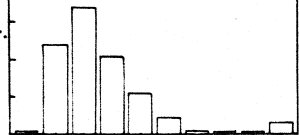

Fig. 7. Vertical variation of grain size parameters in the Voscone stratigraphic type-section. (A) median diameter (Md $\Phi)$ and sorting $(\sigma \Phi)$; (B) skewness $(\alpha \Phi)$ and 2nd skewness $(\alpha 2 \Phi)$; (C) maximum pumice diameter (MP) and maximum lithic diameter (ML) as average diameter of the five largest clasts; (D) histograms of the grain-size distribution.

sub-units) (Fig. 8) and only refers to the equidimensional pumice clasts. Minimum value $\left(290 \mathrm{~kg} \mathrm{~m}^{-3}\right)$ and maximum variability (120 to $\left.450 \mathrm{~kg} \mathrm{~m}^{-3}\right)$ of pumice density are at the top of LFU in V3 layer. Density decreases from bottom to top in LFU (380 to $290 \mathrm{~kg} \mathrm{~m}^{-3}$ ) and increase toward the top in UFU $\left(490 \mathrm{~kg} \mathrm{~m}^{-3}\right)$. Standard deviation ranges from 60 to 100. Density is converted to vesicularity according to Houghton and Wilson (1989) and using a measured DRE (dense-rock equivalent) density value of 2410 $\mathrm{kg} \mathrm{\textrm {m } ^ { - 3 }}$ (see following paragraph). Fig. 9 sum- marises density and vesicularity data for all collected clasts. The data distribution is unimodal, with a vesicularity index of $86 \%$ and a range of $73 \%$ to 95\%. The density, standard deviation and high vesicularity index suggest purely magmatic fragmentation mechanism.

In the Voscone type-section 28 samples were analysed for major elements (XRF). For each subunit, two analyses of a mixture of 10 pumice clasts were performed; in addition in V3 and V5 beds 7 single pumice clasts were analysed. Chemical analy- 
ses of single pumices from V3 and V5 show a very narrow range of values for all major elements except $\mathrm{Na}_{2} \mathrm{O}$. All the samples fall in the field of alkalitrachyte in the TAS diagram and plot on the more evolved side of the evolution trend for the CI eruption products, with $\mathrm{DI}>82$ and $\mathrm{MgO}<0.75$ wt.\% (Civetta et al., 1997). Distribution of the major elements as a function of stratigraphic height shows that the maximum values of the $\mathrm{CaO}(2.26 \mathrm{wt} . \%)$ and $\mathrm{MgO}(0.71$ wt. $\%)$ and the minimum value of $\mathrm{SiO}_{2}$ (61.43 wt.\%) occur in the V1 bed with progressive

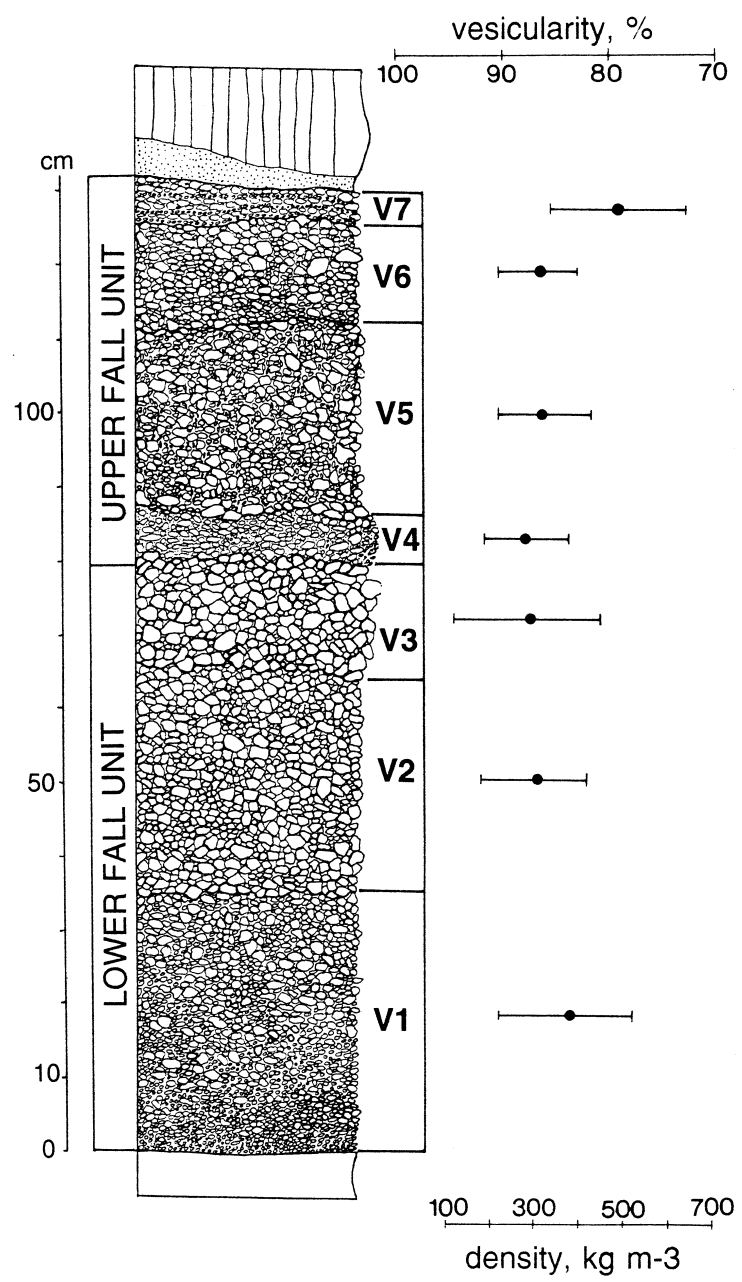

Fig. 8. Vertical variation of pumice clast density in the Voscone stratigraphic type-section. Density means are represented by dots and density ranges by bars.

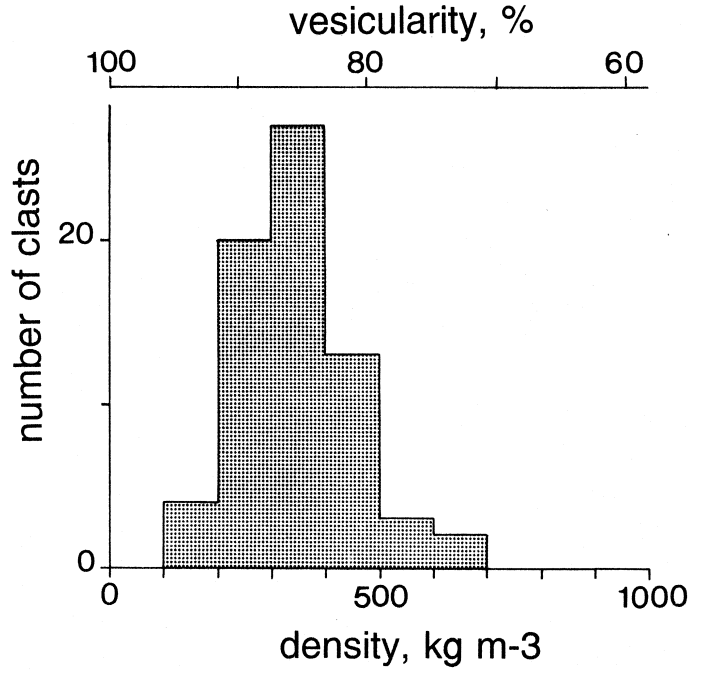

Fig. 9. Density/vesicularity histogram for 70 pumice clasts collected from Campanian Ignimbrite plinian fall deposit in the Voscone section.

decrease of the first two and increase of the latter toward the top of the CI fallout.

\section{Component analysis}

Component analysis was carried out on 7 samples of the Voscone type-section. Four components were distinguished: pumice, accidental lithics, free crystals and obsidian. Clasts larger than $-4 \Phi$ were separated in the field. Sizes between $-3 \Phi$ and $1 \Phi$ were separated in the laboratory under binocular microscope from aliquots containing more than 750 frag-

Table 1

Experimentally measured and mathematically interpolated density values of Campanian Ignimbrite pumice as a function of grain size

\begin{tabular}{lc}
\hline Grain size & Density $\left(\mathrm{kg} \mathrm{m}^{-3}\right)$ \\
\hline$-3 \phi$ & 660 \\
$-2 \phi$ & 680 \\
$-1 \phi$ & 780 \\
$0 \phi$ & 840 \\
$1 \phi$ & 980 \\
$2 \phi$ & 1100 \\
$3 \phi$ & 1450 \\
$4 \phi$ & 1850 \\
$5 \phi$ & 2410 \\
\hline
\end{tabular}


ments (Sparks, 1976). Finer clasts abundances were obtained by counting 750 fragments in thin section. The conversion of data from volume to weight \% was made using standard densities for accidental lithics (trachytic lavas $=2500 \mathrm{~kg} \mathrm{~m}^{-3}$ ) and for crystals (sanidine $=2500 \mathrm{~kg} \mathrm{~m}^{-3}$ ) and experimentally determined densities for pumice. As juvenile clast densities vary with size, a value for the density of the particles of the same pumice clast sampled on the CI proximal deposits, crushed and sieved, was deter- mined from measurements on $-3 \Phi$ to $0 \Phi$ and $5 \Phi$ size classes and from mathematical interpolation on $1 \Phi$ to $4 \Phi$ size classes (Table 1$)$. The density value for the $5 \Phi$ size was considered as DRE density for vesicularity calculations.

Variation of abundance of components vs. stratigraphic height is presented in Fig. 10A. LFU is poorer in free crystals and lithics, and richer in pumice than UFU and both units show well defined internal trends. LFU shows, from bottom to top,
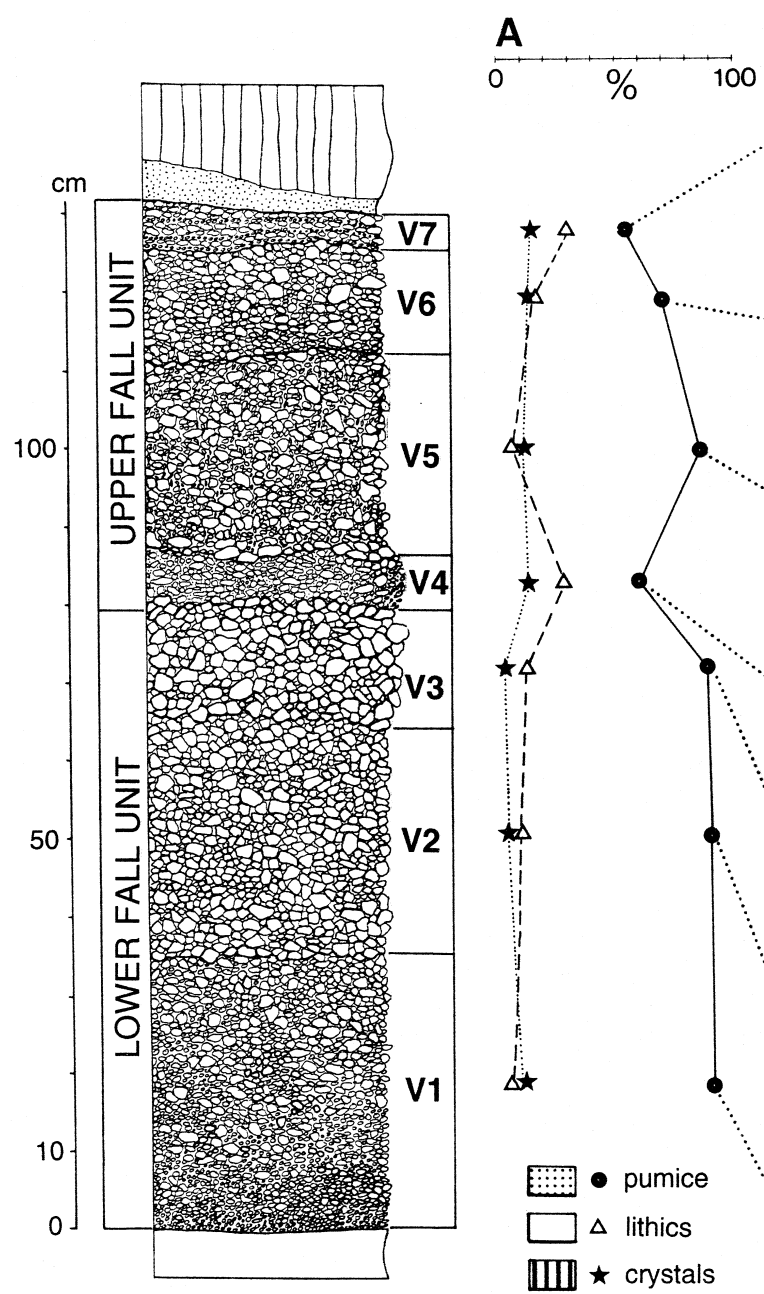

B

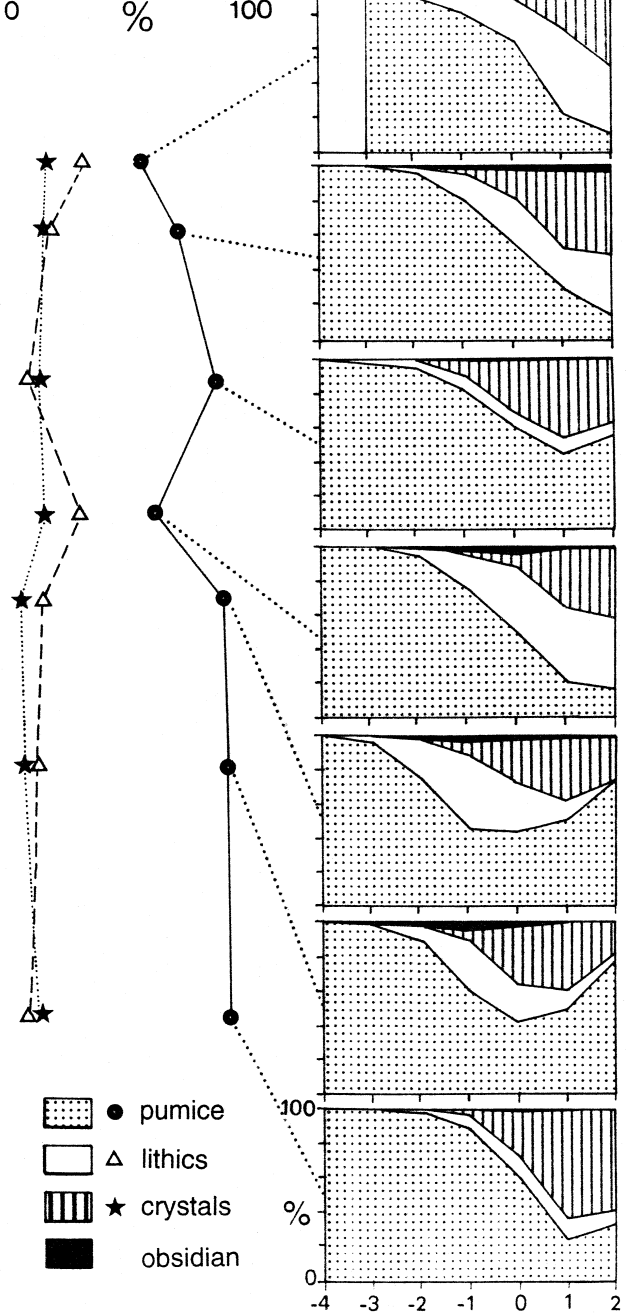

Fig. 10. Vertical variation of the components of the Campanian Ignimbrite plinian fall deposit in the Voscone stratigraphic type-section. (A) bulk percentage of pumice, accidental lithics and crystals; (B) relative proportion (by wt.\%) of pumice, accidental lithics, crystals and obsidian as a function of the grain size. 


\section{LOWER FALL UNIT}
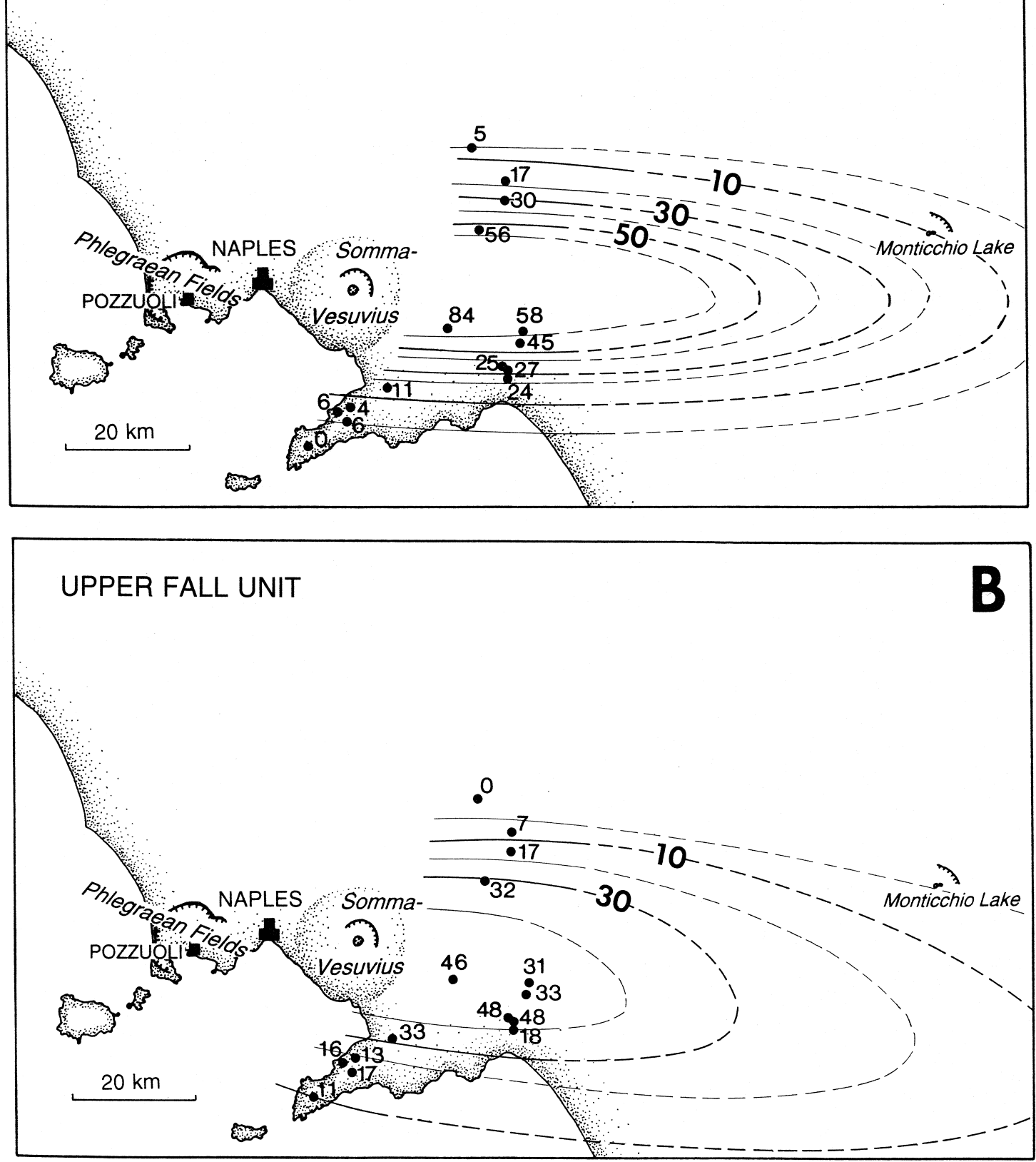

Fig. 11. Thickness characteristics of the Campanian Ignimbrite plinian fall deposit: (A) isopach map of the LFU; (B) isopach map of the UFU. Source vent are considered as the Phlegraean caldera centre (town of Pozzuoli). 

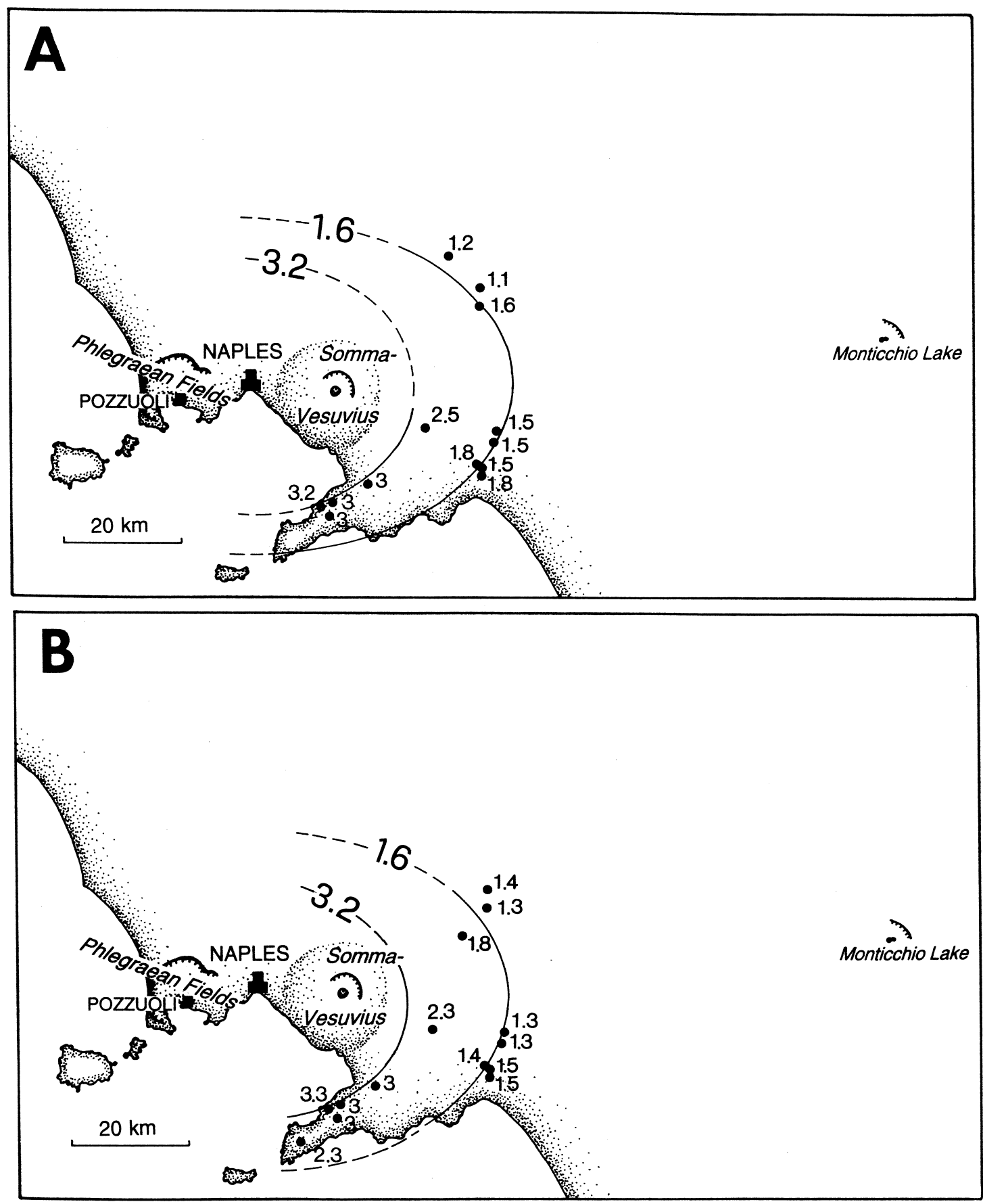

Fig. 12. (A) Isopleth map of lithic clasts of the LFU. (B) Isopleth map of lithic clasts of the UFU. (C) Isopleth map of pumice clasts of the LFU. (D) Isopleth map of pumice clasts of the UFU. 

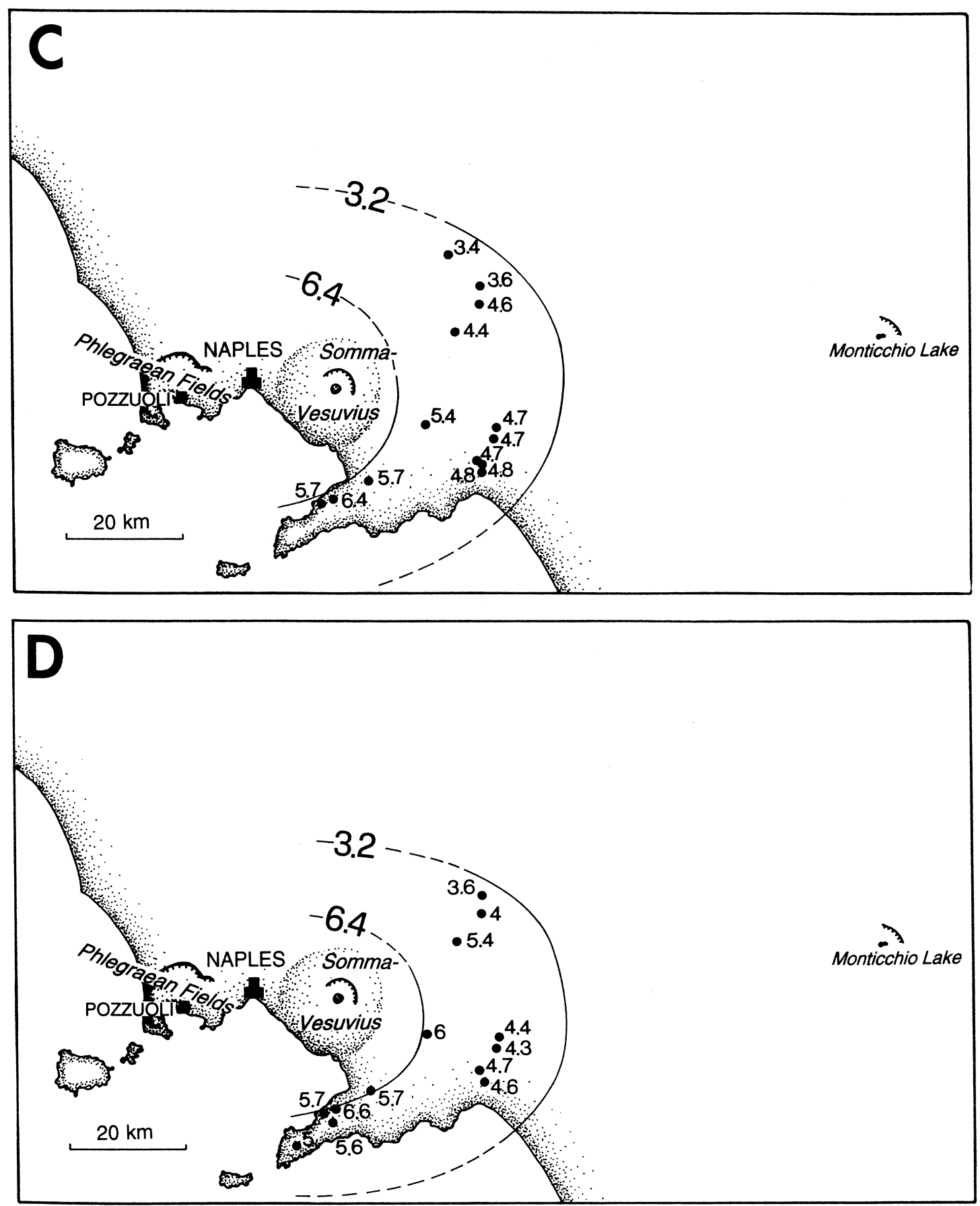

Fig. 12 (continued).

increase in lithics (from 4.0 to $10.5 \mathrm{wt} . \%$ ) and decrease in crystals (from 7.3 to 1.9 wt.\%), while pumice remain almost constant (87-88 wt.\%) and obsidian clasts are rare (1.8 wt.\% max). UFU shows 
at the base (V4) a lithics content of 26.9 wt.\%, a crystals content of $11.5 \mathrm{wt} . \%$ and a pumice content of 59.5 wt.\%. From V5 to V7 lithic and crystals content increase upwards from 5.3 to $29.3 \mathrm{wt} . \%$ and from 9.6 to $14.3 \mathrm{wt} \%$, respectively, whereas the pumice content strongly decreases from 84.9 to 54.0 wt.\%, reaching the similar values to V4. Diagrams of component distribution vs. grain size (Fig. 10B) point out significant differences between LFU and UFU. LFU shows the highest content in lithic clasts in the $-1 \Phi$ and $0 \Phi$ classes, while in the UFU highest lithic clast content occurs in the $2 \Phi$ class. So

\section{Stage I}

(a)

\section{gradually increasing column height (LFU)}
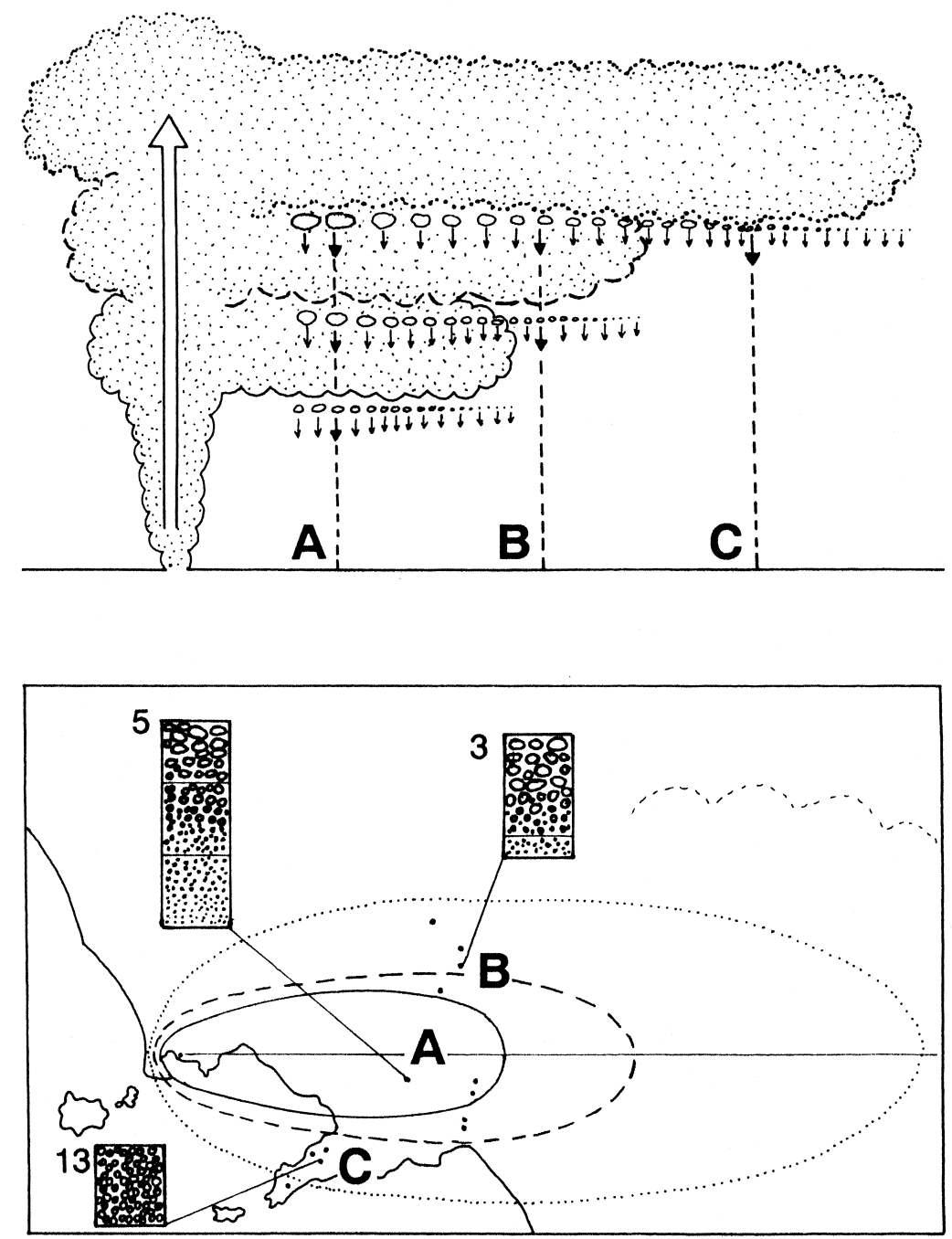

Fig. 13. Dynamics of the plinian column during the Campanian Ignimbrite fall emplacement as reconstructed from the sedimentological features of the LFU and UFU deposits. 


\section{Stage II}

(b)

\section{oscillating column height and pyroclastic flow (UFU)}
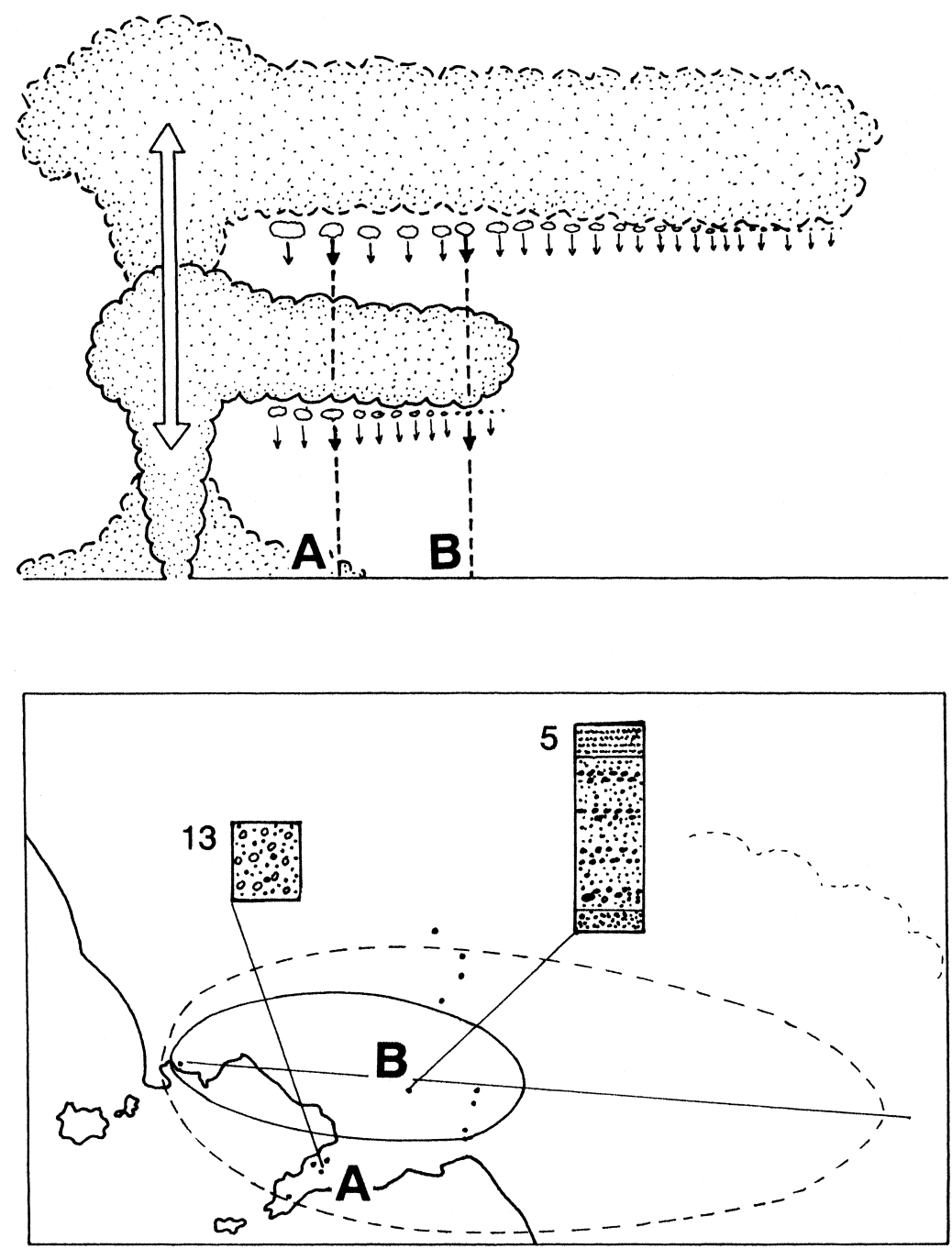

Fig. 13 (continued).

LFU is characterized by the presence of fewer but relative coarse lithic clasts, in contrast UFU has a very high proportion of finer-grained lithic clasts.

\section{Fallout dispersal}

In the absence of proximal exposures of the CI fall we have assumed as a vent area for the deposit the centre of the Phlegraean Fields caldera (town of Pozzuoli). Isopach maps were drawn for LFU and UFU separately, considering that they seems to have slightly different dispersal axes.

The LFU isopach map (Fig. 11A) is constrained by thickness as measured in 14 undisturbed outcrops. Thickness ranges from $4 \mathrm{~cm}$ (sec. 14 Massaquano) to $84 \mathrm{~cm}$ (sec. 5 Voscone), so it was possible to draw isopachs from 5 to $60 \mathrm{~cm}$. Isopachs are fairly well 
constrained in their central part, while towards the distal area they are largely speculative. Some constraint to the distal thickness is provided by the lake Monticchio core (Narcisi, 1996). Isopachs have an elliptical shape with a strong eccentricity. The inferred dispersal axis has an almost perfect eastward direction.

The UFU isopachs (Fig. 11B) are constrained by 14 undisturbed outcrops. Thickness ranges from 7 $\mathrm{cm}$ (sec. 2 Starza) to $48 \mathrm{~cm}$ (sec. 9 Pellezzano), so it was possible to draw isopachs from 5 to $40 \mathrm{~cm}$. As for LFU, isopachs are well constrained only in their central part, while the absence of outcrops allow only tentative tracing in the distal area. Isopachs have an elliptical shape less eccentric than the LFU ones. The inferred dispersal axis has a $\mathrm{N} 95^{\circ}$ direction.

It can be observed that the two dispersal axes are the same as the prevailing winds of the Neapolitan region.

\section{Column height and volume}

In the 15 undisturbed outcrops of the CI pumice fall deposit maximum lithic clasts (ML) and maximum pumice clasts (MP) size were measured for both LFU and UFU. In the Voscone type-section, the measurement was repeated twice for each of its seven layers. MP and ML values are the arithmetic means of five measurements performed in the field in an area of $50 \mathrm{~cm} \times 100 \mathrm{~cm} \times$ the total thickness of each single layer. Isopleth maps of Mp and ML for LFU and UFU are shown in Fig. 12 their isopleths are less well constrained than ML values. This can be attributed to both variability of pumices and possible breakage of pumice upon impact. To partly overcome the first problem only the equidimensional pumices were considered, but even so the density range is still high. ML values are much more reliable and better constrain isopleths, so they were used to get the physical parameters of the eruption.

Both LFU and UFU have consistent ML values, with smooth variations and diminishing values away from the vent and the dispersal axis. The corresponding isopleths have an elliptical shape symmetric to the dispersal axis and cut the isopachs at higher angles approaching to the proximal zone.

The maximum heights of the eruptive columns calculated with the model of the maximum lithic clasts dispersal of Carey and Sparks (1986) is of 44 $\mathrm{km}$ and $40 \mathrm{~km}$ for the LFU and UFU respectively, classifying both pyroclastic falls as ultraplinian.

Volume calculated with the Pyle (1989) method results about $8 \mathrm{~km}^{3}$ for the LFU and $7 \mathrm{~km}^{3}$ for the UFU and is affected by the incertitude of distal isopach tracing.

\section{Discussion and conclusions}

We have documented the presence and characteristics of a major pumice fall deposit at the base of the Campanian Ignimbrite. Because no weathering or surficial erosion (reworked deposits) occur between the fall and the ignimbrite, we conclude that the deposition of the fall shortly preceded that of the ignimbrite. Significant erosion caused by the pyroclastic flow is observed only in the outcrops nearer to the Phlegraean Fields source caldera. This suggests the possibility that the deposit was totally removed nearer to the caldera, where the velocity of the flow was higher.

One of the main result of the study is the identification of two fall units (Lower Fall Unit $=$ LFU and Upper Fall Unit $=$ UFU) with contrasting features, which were produced by two different plinian regimes. The deposit of the UFU exhibits a slightly clockwise rotated dispersal axis relative to the LFU. The rotation might depend either on (1) wind rotation with height during the same eruptive episode or (2) the presence of some time break between the two fall episodes with concurrent change of meteorological conditions.

The plinian regime which led to the deposition of LFU was characterized by a stable plinian plume developed in presence of a strong lateral wind (very good sorting of the deposit) and gradual increase in height of the plume (reverse grading of the deposit) (Fig. 13a). The climax of the plinian phase was attained towards the end of the LFU when the column reached a maximum elevation of $44 \mathrm{~km}$ corresponding to a mass flux of $3.2 \times 10^{8}$ and wind speed eastwards of $>30 \mathrm{~m} \mathrm{~s}^{-1}$. 
The plinian regime which led to the deposition of the UFU was more complex and more difficult to reconstruct. The normal grading of maximum pumice and lithic clasts suggests gradual decrease of the height of the plinian column, i.e., a reduced mass flux of the convective plume (reduced carrying capacity).

Another relevant feature of UFU deposit is the crude stratification due to the overlapping of coarser and finer layers and the overall poor sorting of the deposit. Both these features are consistent with the sedimentation mechanism characterized by alternating showers of finer and coarser materials, but in which the rapid variation of grain size do not permit the deposition of discrete, well sorted beds. These features and, in particular, the lowering of sorting is very prominent towards the top of the fall.

Starting from the general behaviour of the plinian columns, the simplest way to account for the alternating showers of coarser and finer particles is to assume short-term oscillations of the height of the convective plume. Recent experimental and theoretical studies (Woods and Caulfield, 1992; Neri and Dobran, 1994) have actually draw attention to transient oscillations of the convective plumes when eruptive parameters are intermediate between those characteristic of stable convective columns and fully collapsing columns. Woods and Caulfield (1992) have in particular emphasized that when conditions for the onset of collapsing behaviour are achieved, the convection above the vent somehow persists but is characterized by periodic release of thermals. According to the same authors this fact might led to contemporaneity of fallout and flow activity.

A moderately sorted and finer grained fall deposit (unit B3) produced during a period of reduced column height occurred in connection with pyroclastic flow activity has been described in the plinian sequence of May 181980 at Mt. St. Helens (Carey et al., 1990).

We propose that the sedimentological features of the UFU are consistent with the activity of a plinian column dominated by an overall decrease of its height and by periodic oscillations in height (Fig. 13b). Because the gradual decrease of maximum column height of the convective plume during oscillations is inferred from a lowering of the sorting parameter, we also infer that the amplitude of the plume oscillations became larger with time. According to the current theoretical models of plinian columns this fact can be accounted for by (1) an overall decrease of the magma discharge rate at the vent or (2) the onset of partial column collapse which subtracts an increasing mass fraction of pyroclasts from the convective plinian plume. The second hypothesis seems preferable because the high lithic content in the UFU suggests active vent/conduit erosion, this should result in an increase, rather than decrease, in the mass flux at the vent and in a gravitational destabilization of the column.

The possibility that the emplacement of the UFU was coupled with the onset of partial column collapses is not easy to demonstrate because of the lack of exposure of the early deposits of the Campanian Ignimbrite eruption near the Phlegraean Fields source caldera. However, the presence of sporadic deposits of low-grade ignimbrite interbedded between the classic dark-grey, sintered Campanian Ignimbrite and the fall deposit (i.e., a 2-m-thick deposit at Vico Equense, Fig. 3) suggests support for such a hypothesis.

The likelihood of contemporaneity of fall and flow activity during the phase which produced the UFU also opens the possibility that part of the fines, in particular of fine ash $(<1 / 16 \mathrm{~mm})$ found in the UFU, were derived from co-ignimbrite ash fall. This is consistent with the presence of fine ash in the topmost part of the UFU. It is well known that elutriation processes during flow emplacement mainly affect the very fine ash (Woods and Wohletz, 1991). Such a fallout could also have been constrained by ash aggregation promoted by condensation of water vapor (sporadic occurrence of accretionary lapilli at the top of the UFU).

The sedimentological study of the fall deposit underlying the Campanian Ignimbrite leads us to conclude that the transition from the fully convective plinian phase to fully collapsing phase was gradual. During the early phase of collapse the convective column persisted for some time above the vent. Such a column was, however, dominated by continuous oscillation in height which produced continuous variation of the fall grain size over time. In the more proximal area the fall deposit possibly is partial or total reworked by the flow activity. The increase of mass flux observed in the LFU (reverse grading) 
suggests that this factor also controlled the onset of the column collapse and of the emplacement of the UFU fall.

The occurrence of a pyroclastic sequence made up from bottom to top of: (1) inversely graded fall, (2) stratified fall and (3) ignimbrite is not unique to the Campanian Ignimbrite. Similar sequences also occur in the Lower Bandelier Tuff (Otowi Member) in New Mexico.

\section{Acknowledgements}

The research project on the Campanian Ignimbrite was financed by the National Group of Volcanology (C.N.R.). We gratefully acknowledge B.F. Houghton, R.V. Fisher and an anonymous reader for reviewing the manuscript.

\section{References}

Barberi, F., Innocenti, F., Lirer, L., Munno, R., Pescatore, T., Santacroce, R., 1978. The Campanian Ignimbrite: a major prehistoric eruption in the Neapolitan area (Italy). Bull. Volcanol. 41, 10-31.

Carey, S., Sparks, R.S.J., 1986. Quantitative models of the fallout and dispersal of tephra from volcanic eruption columns. Bull. Volcanol. 48, 109-125.

Carey, S., Sigurdsonn, S., Gardner, J.E., Criswell, W., 1990. Variations in column height and magma discharge during the May 18, 1980 eruption of Mt. St. Helens. J. Volcanol. Geotherm. Res. 43, 99-112.

Civetta, L., Orsi, G., Pappalardo, L., Fisher, R.V., Heiken, G., Ort, M., 1997. Geochemical zoning, mingling, eruptive dynamics and depositional processes-the Campanian Ignimbrite, Campi Flegrei caldera, Italy. J. Volcanol. Geotherm. Res. 75, 183-219.
Deino, A., Curtis, G., Rosi, M., 1992. 40Ar/39Ar dating of the Campanian Ignimbrite, Campanian Region, Italy. IGC Kyoto Japan 24 Aug-3 Sept, Abstracts Vol. 3, 633.

Di Girolamo, P., Rolandi, G., Stanzione, D., 1973. L'eruzione di pomici a letto dell'Ignimbrite Campana (Tufo grigio campano Auct.). Per. Mineral. 42, 439-468.

Fisher, R.V., Orsi, G., Ort, M., Heiken, G., 1993. Mobility of large-volume pyroclastic flow-emplacement of the Campanian Ignimbrite, Italy. J. Volcanol. Geotherm. Res. 56, 205220.

Galdieri, G., Paolini, P., 1914. Il tufo campano di Vico Equense. Atti Acc. Sc. Fis. Mat. di Napoli 15 (15), 1-12.

Houghton, B.F., Wilson, C.J.N., 1989. A vesicularity index for pyroclastic deposits. Bull. Volcanol. 51, 451-462.

Narcisi, B., 1996. Tephrochronology of a late quaternary lacustrine record from the Monticchio maar (Vulture Volcano, Southern Italy). Quaternary Sci. Rev. 15, 155-165.

Neri, A., Dobran, F., 1994. Influence of eruption parameters on the thermofluid-dynamics of collapsing volcanic columns. J. Geophys. Res. 99, 11833-11857.

Pyle, D.M., 1989. The thickness, volume and grainsize of tephra fall deposit. Bull. Volcanol. 51, 1-15.

Rosi, M., Sbrana, A., 1987. Phlegrean Fields. CNR Quaderni de 'La Ricerca Scientifica', Roma 114 (9), 1-175.

Rosi, M., Vezzoli, L., Aleotti, P., De Censi, M., 1996. Interaction between caldera collapse and eruptive dynamics during the Campanian Ignimbrite eruption, Phlegraean Fields, Italy. Bull. Volcanol. 57, 541-554.

Scacchi, A., 1888. La regione vulcanica fluorifera della Campania. Atti Acc. Sc. Fis. Mat. di Napoli S. 22 (2), 1-108.

Sparks, R.S.J., 1976. Grain-size variations in ignimbrite and implications for the transport of pyroclastic flows. Sedimentology $23,147-188$.

Thunell, R., Federman, A., Sparks, S., Williams, D., 1979. The origin and volcanological significance of the Y-5 ash layer in the Mediterranean. Quaternary Res. 122, 241-253.

Walker, G.P.L., 1983. Ignimbrite types and ignimbrite problems. J. Volcanol. Geotherm. Res. 94, 65-88.

Woods, A.W., Caulfield, C.P., 1992. A laboratory study of explosive volcanic eruptions. J. Geophys. Res. 97, 6699-6712.

Woods, A.W., Wohletz, K., 1991. Dimensions and dynamics of co-ignimbrite eruption columns. Nature 350, 225-227. 